\title{
Distributions of pigments in reef sediments, contribution of phytoplankton to organic matter budget in coral reef
}

\author{
Mohammed Rasheed $^{{ }^{*} \text {, Tariq Al-Najjar }}{ }^{1}$, Said Damhoureyeh ${ }^{2}$ \\ ${ }^{1}$ Marine Science Station, University of Jordan and Yarmouk University, Aqaba, Jordan; ${ }^{*}$ Corresponding Author: \\ m.rasheed@ju.edu.jo \\ ${ }^{2}$ Biology Department, University of Jordan, Amman, Jordan.
}

Received 22 March 2011; revised 18 April 2011; accepted 27 April 2011.

\begin{abstract}
The temporal distributions of pigment on biogenic calcareous and terrigenic reef sediments, chlorophyll a, chlorophyll $b$, chlorophyll $c$, fucoxanthin, and porphine concentrations were measured monthly in two sediment columns $(0-15 \mathrm{~cm})$ for one year. Pigment concentrations increased significantly during winter (November-April) in both sediment types particularly in the upper layers of the sediments. Phytoplankton contributions to organic matter were found to be $8 \pm 3$ and $6 \pm 2 \%$ in calcareous and terrigenous sediments respectively. The accumulation and the successive degradation of phytoplankton detritus to inorganic nutrients in calcareous sand may partly sustain the productivity of the coral reef communities which live in nutrient-poor environments.
\end{abstract}

Keywords: Pigment; Calcareous Sediments; Terrigenous Sediments

\section{INTRODUCTION}

Organic matter in the water column can be buried into the sediment through precipitation. Some of these compounds can be degraded in the sediment thorough biochemical reactions [1-7]. Shelf and coastal sediments are considered the most productive parts of the ocean floor $[8,9]$. Most of the organic matter sedimentation occurs in the shelf sediments [8]. These sediments are exposed to waves, currents, temperature differences, and nutrient inputs [10]. Due to this high capacity for organic matter, and the exposure of these sediments to different physical and chemical actions, the sediments at coastal regions may have an important regulatory and buffering function in the ocean. The main source of organic matter to the shelf sediments is the deposition of detrital material from the local phytoplankton community in the overlying water which may compromise $20-50 \%$ of the produced organic carbon, nitrogen and phosphorous [11]. Some pigments can be found in the living and deceased phytoplankton as detrital materials as well as in the fecal pellets of the zooplankton.

Calcareous sediments are those of biogenic origin and composed mainly of carbonate while terrigenous sediments are those of land source that have found their way to the land and composed mainly of silicate. Calcareous sediments are usually found in tropical and subtropical environments within coral reef ecosystems. The main component of these sands are coral fragments, mollusc fragments, foraminiferans tests, and calcareous red algae [12]. Due to their different sources, carbonate and silicate sediments have different chemical and physical characteristics, such as porosity, light attenuation, surface structure, sorption and desorption characteristics, as well as different accumulation rate of organic matter $[5,12]$.

The aim of this study was to assess the accumulation rates of some pigments including chlorophyll $a, b, c$, fucoxanthin, and porphine in calcareous and terrigenous sediments of the Gulf of Aqaba during different seasons of the year as well as to estimate the contribution of phytoplankton-pigment to the total organic carbon in calcareous and terrigenous sediments. This work was undertaken to estimate the contribution of phytoplankton detritus in the total organic matter deposited in calcareous and terrigenous sediments in the coral reef areas, since organic matter deposited in coral reef sediments may remineralize to inorganic nutrient and sustain the coral reef system which live in nutrient-poor water.

\section{METHOD}

\subsection{Study Sites}

The study was carried out in a marine reserve thriving 
with coral reef community in the northern Gulf of Aqaba (Figure 1). This reef is considered as one of the bestdeveloped reefs in the Red Sea [13] with high rate of biogenic carbonate production. Two sampling sites at $5 \mathrm{~m}$ water depth were selected for this study; the two sites were 200 meters apart, first site was located in an area with calcareous sediments while the second consisted mainly of terrigenous sediments.

\subsection{Sampling}

At the beginning of this study, physical and chemical properties were analyzed. Cores of sediment to about 20 $\mathrm{cm}$ sediment depth were sampled monthly for pigment analysis using cylindrical acrylic pipes $(25 \mathrm{~cm}$ high, 9.5 $\mathrm{cm}$ inner diameter). In the lab, the sediments of the cores were cut into slices as thin as $1 \mathrm{~cm}$ in the first $6 \mathrm{~cm}$ of the sediment and $2 \mathrm{~cm}$ subsequently. About $5 \mathrm{~cm}^{3}$ of the sediment were kept in deep freeze $-80^{\circ} \mathrm{C}$ for pigment analysis.

\subsection{Analytical Procedures}

\subsubsection{Sediment Properties}

Grain size distribution of the sediment has been assessed by set of calibrated analytical sieves. Sediment porosities were calculated from weight loss of wet sediment after drying at $60^{\circ} \mathrm{C}$ for $24 \mathrm{~h}$. The hydraulic conductivity (permeability) of the sediment was measured with a constant head permeameter as described by Klute and Dirksen [14]. Calcium carbonate content was determined by complexometric titration of calcium carbonate with $0.1 \mathrm{~N}$ of HCL according to Muller [15]. Organic carbon contents in the sediments were measured following the method of Sandstrom [16], at which $0.2 \mathrm{~g}$ of the

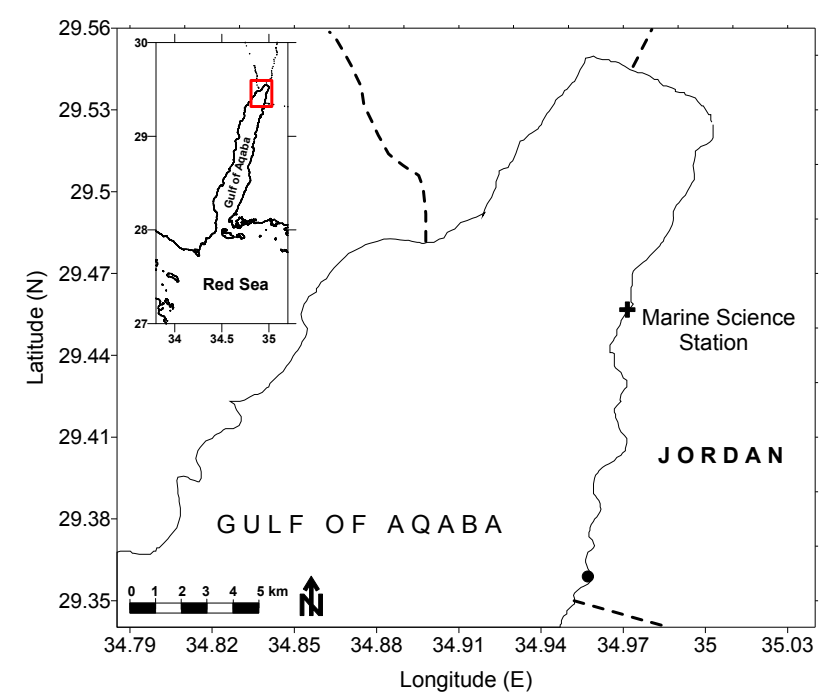

Figure 1. Study sit at the northern Gulf of Aqaba, Red Sea. sediment were treated with concentrated $\mathrm{H}_{2} \mathrm{SO}_{4}$ and potassium dichromate and then titrated with ferrous ammonium sulfate solution.

\subsubsection{Pigment Analysis}

Pigments were analysed following the method of Rusch et al. [17]. Accordingly, 90\% acetone was used for pigment extraction and then the extract was obtained by centrifugation at $4^{\circ} \mathrm{C}$ for 15 minutes at $15000 \mathrm{rpm}$. The supernatant was filtered through $20 \mu \mathrm{m}$ syringefilter and concentrated using opaque vacuum oven. $20 \mu \mathrm{l}$ of the extracted pigment were injected and separated through a Hypersil ODS C18 column $[17,18]$. The analysis was done in duplicates for each sediment sample.

\section{RESULTS}

\subsection{Sediment Properties}

Calcareous sediments have more carbonate content than terrigenous sediments (about 18 fold, Table 1). This is expected as the source of calcareous sands is biogenic with carbonate body. Grain size, porosity, and permeability are obviously higher in the calcareous sands than in the terrigenous sands which emphasize the different sources of the two sediments and that the granules of the calcareous sands are non regular and have more bores. Although calcareous sands have larger grain size, higher organic carbon is found in these sands indicating also the biogenic source of these sediments and higher surface area [5].

\subsection{Pigment Distribution in Sediments}

The northern Gulf of Aqaba has usually four specified conditions which control nutrients, organic matter and phytoplankton spatial distributions in the coastal water [5,19-22]. These conditions prevailing in four different periods are 1) summer months which extend usually from June to November with low nutrients, organic matter and phytoplankton level 2) transition month between summer and winter (December) 3) winter months (January-April) with high nutrient, organic matter concentrations as well as high phytoplankton level 4) transition month between winter and summer (May). The data shown in (Figure 2, August, December, March, and May) is to characterize pigment concentrations. Pigment concentrations at all months decline from the upper layer of the sediments to the bottom layers (Figure 2). Yet, subsurface maxima can be observed in some months for calcareous sediments (e.g. chl $b$-December at $1 \mathrm{~cm}$ sediment depth). Chlorophyll $a$ profiles showed an increase in the concentrations from August to March in both sediment types (Figure 2). However, a significant in- 
(August)
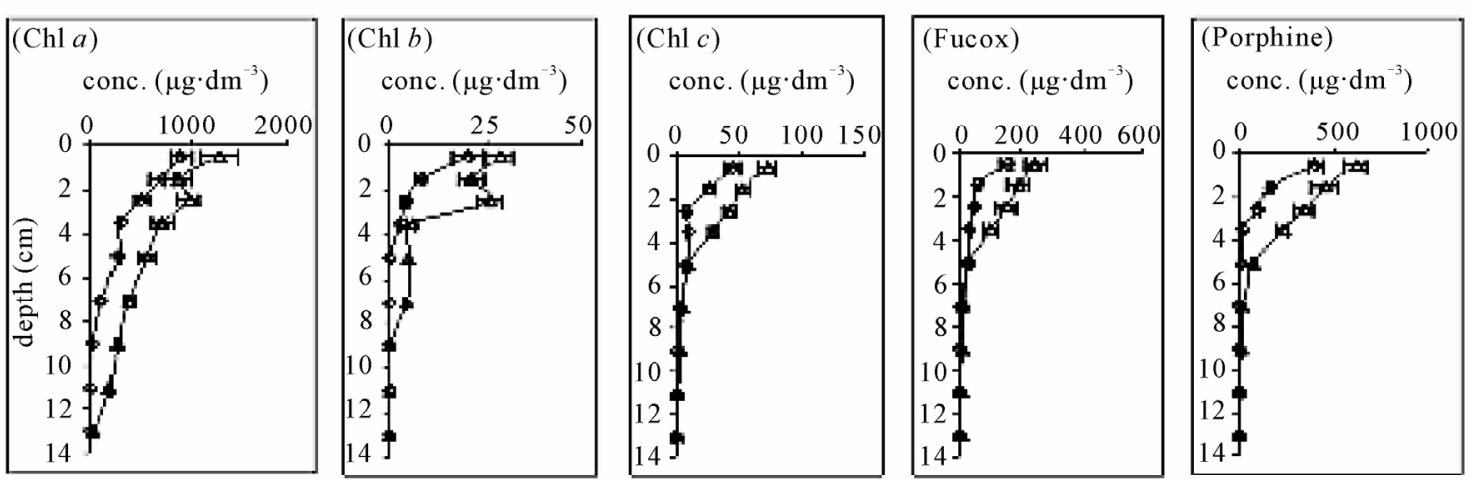

(December)
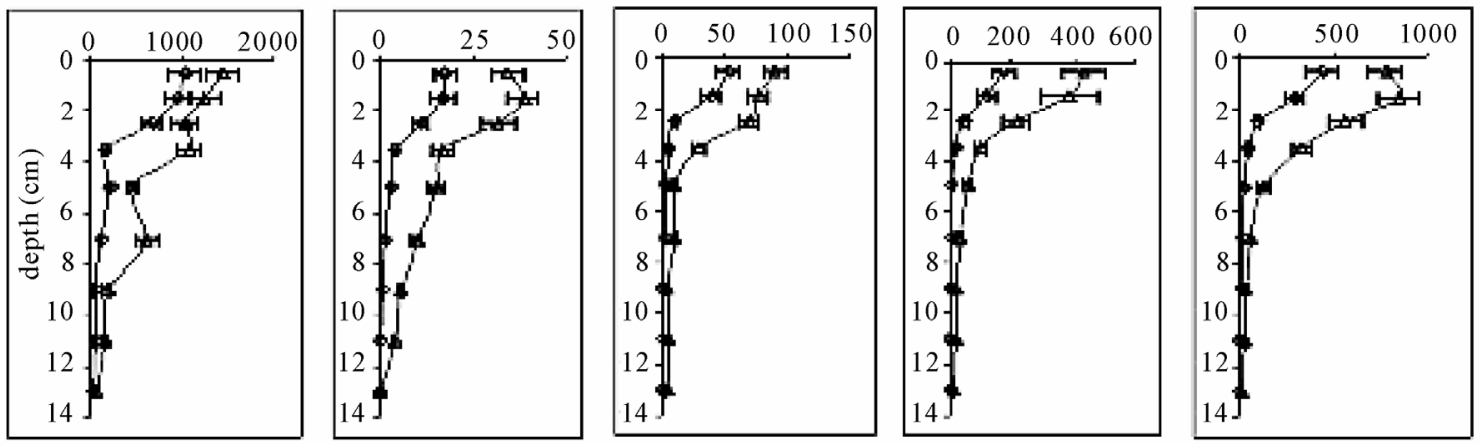

(March)
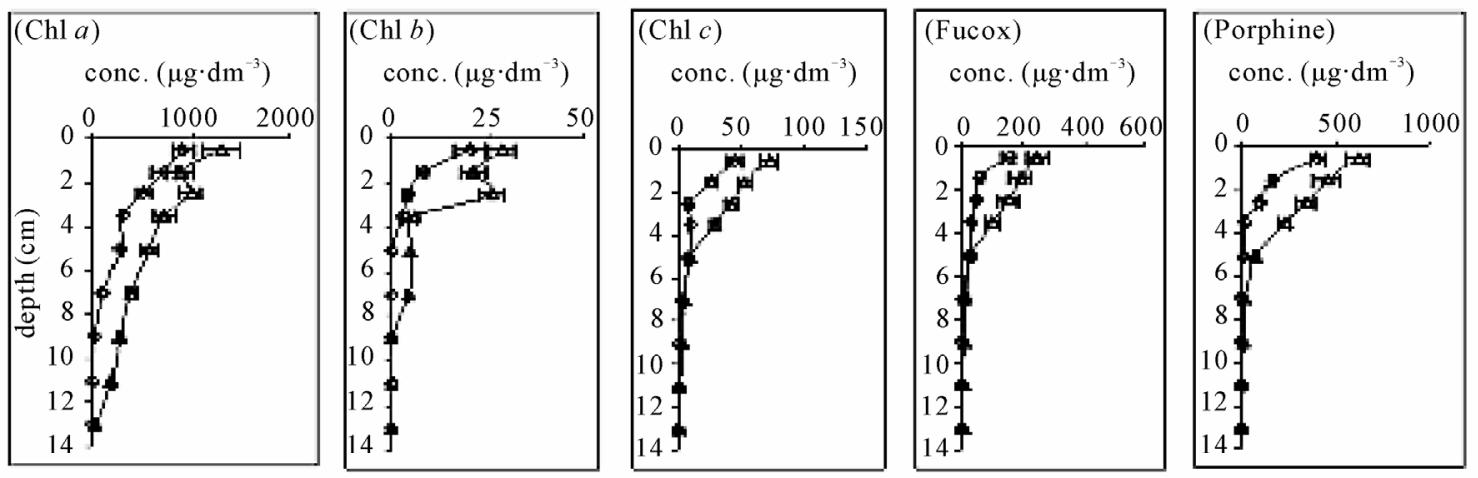

(May)
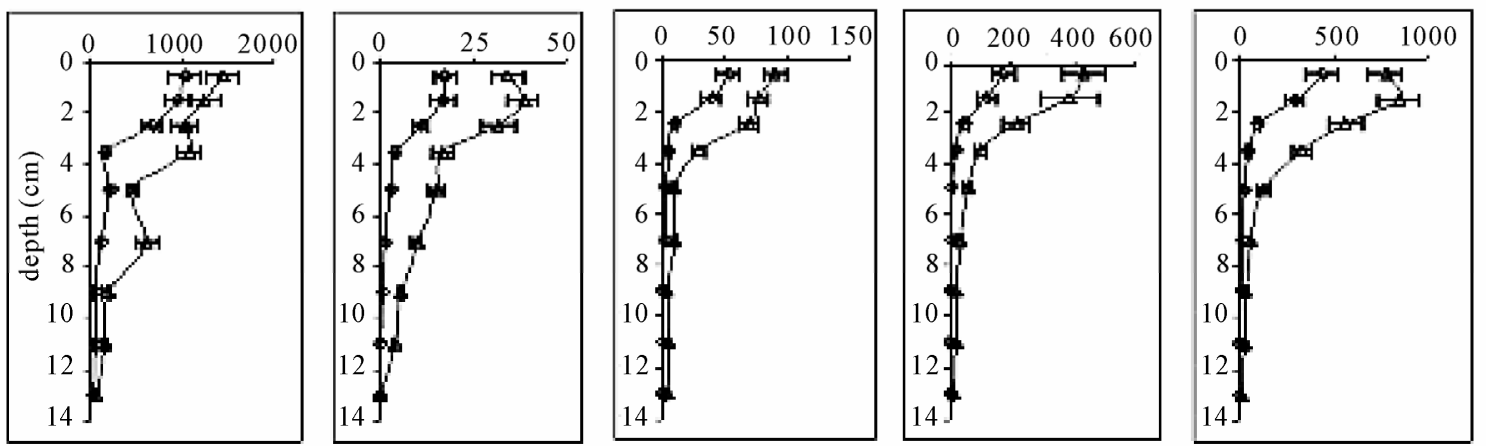

Figure 2. Pigment concentrations $\left(\mu \mathrm{g} \cdot \mathrm{dm}^{-3}\right)$ in calcareous (triangle) and terrigenous (square) sediments in August, December, March and May. Complete data sets including the whole year (January - December) are available from the authors. The error bars represent the standard deviation of two measured samples from the same sediment depth. 
Table 1. Chemical and physical properties of calcareous and terrigenous sediments.

\begin{tabular}{cccccccc}
\hline Sediment type & $\mathrm{CaCO}_{3}(\%)$ & $\begin{array}{c}\text { Median grain } \\
\text { size }(\mu \mathrm{m})\end{array}$ & $\begin{array}{c}\text { Mean grain size } \\
(\mu \mathrm{m})\end{array}$ & Sorting & Porosity $(\%)$ & $\begin{array}{c}\text { Permeability } \\
\left(\mathrm{m}^{2 *} 10^{-12}\right)\end{array}$ & $\begin{array}{c}\text { Organic carbon } \\
(\%)\end{array}$ \\
\hline Calcareous & $70-90$ & 605 & 545 & 1.3 & $52 \pm 6$ & $135 \pm 18$ & $0.41 \pm 0.1$ \\
Terrigenous & $3-6$ & 230 & 258 & 0.8 & $35 \pm 5$ & $22 \pm 6$ & $0.26 \pm 0.1$ \\
\hline
\end{tabular}

crease in the upper layer of the sediments was observed, while no change was observed in the bottom layers (Figure 2). similar trends were noticed for other pigments. Comparison between the calcareous and terrigenous sediments showed that calcareous sediments have higher concentrations than terrigenous sediments (Figure 2). This is more pronounced in the middle and deep layer as indicated by the ratio of individual pigment in calcareous to terrigenous sediments (Table 2).

\section{DISCUSSION}

The results revealed two important aspects. The seasonal patterns of pigments concentrations in both sediment types and the elevated pigments concentrations in calcareous sediments compared to those of terrigenous silicate sediments.

\subsection{Seasonal Pattern}

Higher pigment concentrations were measured in the sediment in winter than the summer (Figure 2). This was clearly obvious in the upper layers of the sediments (Table 3). The rates of pigment changes were always positive in the upper layer $(0-2)$ compared to fluctuated values in the middle and lower layers of the sediments (Table 3), indicating that the upper layers were impacted by seasonal pattern existing in the Gulf of Aqaba [19-22]. Low nutrients and chlorophyll $a$ concentration were found in the water column at coastal and offshore waters during summer, while in winter, high concentrations were attributed to intrusion of nutrient and organic matter rich water from deep water to the shallow and coastal water [5]. This might impact pigment concentrations directly by intrusion of organic matter rich in plankton detritus from deep water [21] and indirectly by primary productivity enhance and phytoplankton bloom due to availability of different nutrients [23-26]. Furthermore, tight coupling between seasonal changes in the water column and permeable sediments was found [5] in the northern Gulf of Aqaba and in the North Sea [27].

\subsection{Pigment Distributions in Calcareous and Terrigenous Sediments}

The concentrations of different pigments in calcareous sediments were obviously higher than those of silicate sediments especially in the upper $(0-2 \mathrm{~cm})$ and the middle layers $(2-8 \mathrm{~cm})$ of the sediments (Figure 2), where bioturbation and advective process may effect the transport mechanism in the sediments $[28,29]$. This implied that organic matter was trapped more in calcareous sediments which might be caused by different properties of calcareous and terrigenous sediments such as mineral structure, surface area, permeability and porosity of the sediment as well as the benthic fauna that present at both sites.

Although grain sizes of calcareous sediments was higher than these of terrigenous sediments, higher surface area of calcareous sediments was measured for the sediment of the Gulf of Aqaba $\left(0.41\right.$ and $0.27 \mathrm{~m}^{2} \cdot \mathrm{g}^{-1}$ for calcareous, and terrigenous respectively [5]. Calcareous sediments with a rough surface $[5,30]$ which originated from skeletal remain of corals, sea urchins, and other benthic organisms, contained many small pores that increase the surface area of the calcareous grains. The high surface area then enhanced the ability of the sediment to accumulate more organic matter [31-33]. Rasheed et al. [5] using fluoresceine as inert tracer, found higher accumulation rate ( 1.3 fold) in calcareous sediment than in terrigenic sediment and related this to less rounded shape and rough grain surface of the calcareous sediments. The in-situ accumulation rate in calcareous and terrigenous sediments revealed more organic matter accumulated in the calcareous sediments (factor 1.5) which is attributed to a higher grain surface area of the calcareous sediments. The upper layers of the coral sands are well aerated and illuminated and are inhabited by dense populations of microalgae, bacteria and microzoobenthos [34]. This would increase subsequently pigment concentrations in these sands.

Higher permeability was measured in calcareous sediment compared to terrigenous sediments ( 6 fold, Table 1). This might increase the accumulation rate of the calcareous sand as demonstrated by several authors [5,12,30,35-38]. The in situ incubation to investigate trapping efficiency of organic particles in sieved carbonate and silicate sediments with different permeability revealed 2-fold of pigment concentrations were trapped in the calcareous than in the terrigenous sediments and pigments penetrated deeper into the these sediment [5]. The high porosity and permeability of carbonate sediments allow water currents to penetrate and resuspend 
Table 2. Average ratios between pigment concentrations in calcareous and terrigenous sediments from different layer of the sediment. Surface sediments are represented by $0-2 \mathrm{~cm}$ layer, middle sediments are represented by $2-8 \mathrm{~cm}$ layer, and bottom sediments are represented by $8-15 \mathrm{~cm}$ layer.

\begin{tabular}{|c|c|c|c|c|c|c|}
\hline Period & Layer (cm) & $\operatorname{chl} a$ & $\operatorname{chl} b$ & $\operatorname{chl} c$ & fucoxanthin & porphine \\
\hline \multirow{3}{*}{ Summer } & $0-2$ & 1.3 & 1.7 & 1.7 & 1.7 & 1.7 \\
\hline & $2-8$ & 2.2 & 4.2 & 3.1 & 3.2 & 4.1 \\
\hline & $8-15$ & 4.5 & 1.5 & 4.8 & 5.1 & 4.9 \\
\hline \multirow{3}{*}{ December } & $0-2$ & 1.4 & 2.1 & 1.8 & 2.7 & 2.3 \\
\hline & $2-8$ & 2.5 & 3.6 & 6.3 & 4.9 & 6.2 \\
\hline & $8-15$ & 5.1 & 10.2 & 5.9 & 5.4 & 5.4 \\
\hline \multirow{3}{*}{ Winter } & $0-2$ & 0.9 & 1.4 & 1.3 & 1.5 & 1.3 \\
\hline & $2-8$ & 1.8 & 1.8 & 3.9 & 4.2 & 6.3 \\
\hline & $8-15$ & 4.6 & 2.3 & 1.1 & 1.0 & 5.8 \\
\hline \multirow{3}{*}{ April } & $0-2$ & 1.3 & 2.0 & 2.0 & 2.0 & 2.0 \\
\hline & $2-8$ & 2.6 & 3.5 & 4.0 & 4.2 & 7.7 \\
\hline & $8-15$ & 7.3 & 6.2 & 1.3 & 1.2 & 7.2 \\
\hline
\end{tabular}

Table 3. Rates of pigments changes $\left(\mathrm{mg} \cdot \mathrm{dm}^{-3} \cdot \mathrm{d}^{-1}\right)$ during winter period (November - March) in calcareous and terrigenous sediments. Rates are calculated from concentration differences between March and November divided by periods.

\begin{tabular}{|c|c|c|c|c|c|c|c|c|c|c|}
\hline \multirow{2}{*}{ Layer $(\mathrm{cm})$} & \multicolumn{2}{|c|}{$\operatorname{chl} a$} & \multicolumn{2}{|c|}{$\operatorname{chl} b$} & \multicolumn{2}{|c|}{$\operatorname{chl} c$} & \multicolumn{2}{|c|}{ fucoxanthin } & \multicolumn{2}{|c|}{ porphine } \\
\hline & $\mathrm{C}$ & $\mathrm{T}$ & $\mathrm{C}$ & $\mathrm{T}$ & $\mathrm{C}$ & $\mathrm{T}$ & $\mathrm{C}$ & $\mathrm{T}$ & $\mathrm{C}$ & $\mathrm{T}$ \\
\hline $0-2$ & 5.48 & 3.38 & 0.16 & 0.08 & 0.37 & 0.13 & 1.78 & 0.08 & 3.38 & 0.88 \\
\hline $2-8$ & 1.05 & -0.12 & 0.00 & 0.06 & 0.12 & 0.01 & 0.56 & -0.01 & 5.49 & -0.26 \\
\hline $8-15$ & -1.29 & -1.25 & -0.01 & -0.02 & 0.01 & 0.10 & 0.02 & 0.04 & 0.07 & -0.10 \\
\hline
\end{tabular}

sand $[39,40]$, which enhance advective transport through these sediments. In high permeable sand, advective exchange may be dominant which increase the flow of water with particulate matter into the sediments [5]. Flume experiments showed that the ensuing advective pore water flows could transport solutes and particulate matter up to 10 centimeters into the bed within 12 hours $[36,41,42]$. In our experiment, the calcareous sand accumulated pigments deeper than terrigenous sand (e.g. chlorophyll a was transported to $11 \mathrm{~cm}$ and $7 \mathrm{~cm}$ into calcareous and terrigenous sediments respectively). As calcareous sediments had higher permeability than terrigenic, organic matter could be transported and accumulated deeper into these sediments. Rasheed et al. (2003 a) found that organic matter transported 2.5 and $1.5 \mathrm{~cm}$ deep into carbonate and silicate sediments respectively. This was caused according to the authors by advective pore water flows. Pilditch and Grant [35] and Huettel and Rusch [36] demonstrated in flume experiments that permeable sand beds could filter phytoplankton from the boundary layer. Horizontal pressure gradients, generated when the boundary flows interact with small sediment topography (sand ripples, biogenic structures, shells) causing water intrusion into the bed which will transport suspended particles into the sediment.

Benthic fauna might also effect pigment distribution in the sediment either through bioturbation [29] or by feeding activities. The distribution of organic matter at both sediment sites revealed more shells and snails in calcareous sediments than in terrigenous sediments. This might increase pigment content in the deep layers of the calcareous sediments more than those of the terrigenous sediments [5].

\subsection{Phytoplankton Contribution to Total Organic Matter Budget in Coral Reefs}

Calcareous sediments are dominant in the continental shelves where coral reefs are present [34]. Through transportation of solute into the sediments through advective process, calcareous sediments filter these solutes 
and the trapped particulate matter present. Phytoplankton detritus can be also trapped in the sediments. In order to calculate the contribution of phytoplankton detritus in total organic matter deposited in calcareous and terrigenous sediments, the conservative calculations using the accumulative rates of chl $a$ and fucaxanthin in the sediment and the pigment concentration percentage for the total phytoplankton in the Gulf of Aqaba during winter season were 28 and $12 \%$ respectively [20], however, we found phytoplankton contributions of $8 \pm 3$ and $6 \pm 2 \%$ of organic matter to calcareous and terrigenous sediments respectively. The accumulation of phytoplankton detritus and the subsequent degradation of these detritus to inorganic nutrients may partly support the productivity of the coral reef community which lives in nutrient-poor environments.

\section{ACKNOWLEDGEMENTS}

Thanks are due to Khalid Altrabeen for his help in the lab. We would like to thank Tariq Al-Salaman and Ali Hammad for helping in the collection of the samples. This work has been funded by the Marine Science Station, Aqaba-Jordan.

\section{REFERENCES}

[1] Charpy-Roubaud, C.J., Charpy, L. and Cremoux, J.L. (1990) Nutrient budget of the lagoonal waters in an open central South-Pacific atoll (Tikehau, Tuamotu, French Polynesia). Marine Biology, 107, 67-73.

doi:10.1007/BF01313243

[2] Rysgaard, S., Thamdrup, B., Risgaard-Petersen, N., Fossing, H., Berg, P., Christensen, P.B. and Dalsgaard, T. (1998) Seasonal carbon and nutrient mineralization in a high-Arctic coastal marine sediment, young sound, Northeast Greenland. Marine Ecology Progress Series, 175, 261-276. doi:10.3354/meps175261

[3] Ciceri, G., Ceradini, S. and Zitelli, A. (1999) Nutrient benthic fluxes and pore water profiles in a shallow brackish marsh of the lagoon of Venice. Annali Di Chimica, 89, 359-375.

[4] Wild, C., Rasheed, M., Werner, U., Franke, U., Johnston, R. and Huettel, M. (2004) Degradation and mineralization of coral mucus in reef environments. Marine Ecology - Progress Series, 267, 159-171. doi: $10.3354 /$ meps 267159

[5] Rasheed, M., Badran, M.I. and Huettel, M. (2003) Particulate matter filtration and seasonal nutrient dynamics in permeable carbonate and silicate sands of the Gulf of Aqaba, Red Sea. Coral Reefs, 22, 167-177. doi:10.1007/s00338-003-0300-y

[6] Rasheed, M., Wild, C., Jantzen, C. and Badran, M. (2006) Mineralization of particulate organic matter derived from coral-reef organisms in reef sediments of the Gulf of Aqaba. Chemistry \& Ecology, 22, 13-20. doi: $10.1080 / 02757540500456823$

[7] Wild, C., Naumann, M., Haas, A., Struck, U., Mayer, F., Rasheed, M. and Huettel, M. (2009) Coral sand O2 uptake and pelagic-benthic coupling in a subtropical fring- ing reef, Aqaba, Red Sea. Aquatic Biology, 6, 133-142. doi:10.3354/ab00181

[8] Jorgensen, B.B. (1983) Processes at the sediment-water interface. In: Bolin, B. and Cook, R.B. Eds., The Major Biochemical Cycles and Their Interactions, John Wiley, New York, 477- 515.

[9] Jorgensen, B.B. (1996) Material flux in the sediment. In: Jorgensen, B.B. and Richardson, K. Eds., Eutrophication in Coastal Marine Ecosystems, American Geophysical Union, Washington, 115-135.

[10] Kristensen, E., Jensen, M.H., Jensen, K.M. (1997) Temporal variations in microbenthic metabolism and inorganic nitrogen fluxes in sandy and muddy sediments of a tidally dominated bay in the northern Wadden Sea. Helgoland Marine Research, 51, 295-320.

[11] Wollast, R. (1991) The coastal organic carbon cycle: Fluxes, sources, and sinks. In: Mantoura, R.F.C., Martin, J.M. and Wollast, R. Eds., Ocean Margin Processes in Global Change, Wiley, Chichester, 365-381

[12] Rasheed, M., Badran, M.I. and Huettel, M. (2003) Influence of sediment permeability and mineral composition on organic matter degradation in three sediments from the Gulf of Aqaba, Red Sea. Estuarine, Coastal and Shelf Science, 57, 369-384. doi:10.1016/S0272-7714(02)00362-1

[13] Friedman, G.M. (1968) Geology and geochemistry of reefs, carbonate sediments, and waters, Gulf of Aqaba (Elat), Red Sea. Journal of Sedimentary Research, 38, 895-919.

[14] Klute, A. and Dirksen, C. (1986) Hydraulic conductivity and diffusivity: Laboratory methods. In: Klute, A. Ed., Methods of Soil Analysis - Part 1 - Physical and Mineralogical Methods, American Society of Agronomy, Madison, 687-734.

[15] Muller, G. (1967) Methods in sedimentary petrology. Hafner Publishing Company, New York, 255.

[16] Sandstrom, M.W., Tirendi, F. and Nott, A. (1986) Direct determination of organic carbon in modern reef sediments and calcareous organisms after dissolution of carbonate. Marine Geology, 70, 321-329. doi:10.1016/0025-3227(86)90009-5

[17] Rusch, A., Forster, S. and Huettel, M. (2001) Bacteria, diatoms and detritus in an intertidal sandflat subject to advective transport across the water-sediment interface. Biogeochemistry, 55, 1-27. doi:10.1023/A:1010687322291

[18] Karsten, U. and Garcia-Pichel, F. (1996) Carotenoids and mycosporine-like amino acid compounds in members of the genus Microcoleus (cyanobacteria): A chemosystematic study. Systematic and Applied Microbiology, 19, 285-294.

[19] Badran, M.I. and Foster, P. (1998) Environmental quality of the Jordanian coastal waters of the Gulf of Aqaba, Red sea. Aquatic Ecosystem Health \& Management, 1, 75-89.

[20] Al-Najjar, T. and Rasheed, M. (2005) Zooplankton biomass in the most northern tip of the Gulf of Aqaba, a case study. Lebanese Science Journal, 6, 3-10.

[21] Rasheed, M., Badran, M.I., Richter, C. and Huettel, M. (2002) Effect of reef framework and bottom sediment on nutrient enrichment in a coral reef of the Gulf of Aqaba, Red Sea. Marine Ecology-Progress Series, 239, 277-285. doi:10.3354/meps239277 
[22] Acker, J., et al. (2008) Remotely-sensed chlorophyll a observations of the northern Red Sea indicate seasonal variability and influence of coastal reefs. Journal of Marine Systems, 69, 191-204. doi:10.1016/j.jmarsys.2005.12.006

[23] Levanon-Spanier, I., Padan, E. and Reiss, Z. (1979) Primary production in a desert enclosed sea-the Gulf of Elat (Aqaba), Red Sea. Deep Sea Research, 26, 673-685. doi:10.1016/0198-0149(79)90040-2

[24] Badran, M.I. (2001) Dissolved oxygen, chlorophyll a and nutrients: Seasonal cycles in waters of the Gulf Aqaba, Red Sea. Aquatic Ecosystem Health \& Management, 4, 139-150. doi:10.1080/14634980127711

[25] Aberle, N., et al. (2009) Differential routing of "new" nitrogen toward higher trophic levels within a marine food web of the Gulf of Aqaba, Northern Red Sea, Marine Biology, 157, 157-169. doi:10.1007/s00227-009-1306-y

[26] Yahel, G., Post, A., Fabricius, K., Vaulot, D. and Genin, A. (1998) Phytoplankton distribution and grazing near coral reef. Limnology and Oceanography, 43, 551-563. doi:10.4319/1o.1998.43.4.0551

[27] Lohse, L., Malschaert, J.F.P., et al. (1995) Sediment-water fluxes of inorganic nitrogen compounds along the transport route of organic matter in the North Sea. Ophelia, 41, 173-197.

[28] Huettel, M. and Gust, G. (1992) Impact of bioroughness on interfacial solute exchange in permeable sediments. Marine Ecology Progress Series, 89, 253-267. doi:10.3354/meps089253

[29] Boudreau, B.P. (1998) Mean mixed depth of sediments: The wherefore and the why. Limnology and Oceanography, 43, 524-536. doi:10.4319/lo.1998.43.3.0524

[30] Wild, C., Rasheed, M., Werner, U., Franke, U., Johnston, R. and Huettel, M. (2004) Degradation and mineralization of coral mucus in reef environments. Marine Ecology Progress Series, 267, 159-171. doi: $10.3354 /$ meps 267159

[31] Mayer, L.M. (1994) Relationships between mineral surfaces and organic carbon concentrations in soils and sediments. Chemical Geology, 114, 347-363. doi:10.1016/0009-2541(94)90063-9

[32] Mayer, L.M. (1994) Surface area control of organic carbon accumulation in continental shelf sediments. Geochimica et Cosmochimica Acta, 58, 1271-1284. doi:10.1016/0016-7037(94)90381-6
[33] Adams, R.S. and Bustin, R.M. (2001) The effects of surface area, grain size and mineralogy on organic matter sedimentation and preservation across the modern Squamish Delta, British Columbia: The potential role of sediment surface area in the formation of petroleum source rocks. International Journal of Coal Geology, 46, 93-112. doi:10.1016/S0166-5162(01)00019-2

[34] Sorkin, Y.I. (1995) Coral reef ecology. Ecological studies. Springer-Verlag, Berlin.

[35] Pilditch, C.A. and Grant, J. (1999) Effect of variations in flow velocity and phytoplankton concentration on sea scallop Placopecten magellanicus grazing rates. Journal of Experimental Marine Biology and Ecology, 240, 111136. doi:10.1016/S0022-0981(99)00052-0

[36] Huettel, M. and Rusch, A. (2000) Transport and degradation of phytoplankton in permeable sediment. Limnology and Oceanography, 45, 534-549. doi: $10.4319 /$ lo.2000.45.3.0534

[37] Jahnke, R.A., Nelson, J.R., Marinelli, R.L. and Eckman, J.E. (2000) Benthic flux of biogenic elements on the Southeastern US continental shelf: Influence of pore water advective transport and benthic microalgae. Continental Shelf Research, 20, 109-127. doi:10.1016/S0278-4343(99)00063-1

[38] Rusch, A. and Huettel, M. (2000) Advective particle transport into permeable sediments - evidence from experiments in an intertidal sandflat. Limnology and Oceanography, 45, 525-533. doi:10.4319/10.2000.45.3.0525

[39] Buddemeier, R.W. and Oberdorfer, J.A. (1986) Internal hydrology and geochemistry of coral reefs and atoll islands: Key to diagenetic variations. In: Schroeder, J.H. and Purser, B.H. Eds., Reef Diagenesis, Springer, Berlin, 91-112.

[40] Riegl, B. (1995) Effects of sand deposition on scleractinian and alcyonacean corals. Marine Biology, 121, 517526. doi:10.1007/BF00349461

[41] Huettel, M., Ziebis, W. and Forster, S. (1996) Flow-induced uptake of particulate matter in permeable sediments. Limnol Oceanogr, 41, 309-322. doi:10.4319/10.1996.41.2.0309

[42] Huettel, M., Ziebis, W., Forster, S. and Luther, G.L. (1998) Advective transport affecting metal and nutrient distribution and interfacial fluxes in permeable sediments. Geochimica et Cosmochimica Acta, 62, 613-631. doi:10.1016/S0016-7037(97)00371-2 